DOI $10.52727 / 2078-256 X-2021-17-3-41-41$

\title{
ДИНАМИЧЕСКАЯ МРТ В КОЛИЧЕСТВЕННОЙ ОЦЕНКЕ НАРУШЕНИЙ ГЕМАТОМИОКАРДИАЛЬНОГО БАРЬЕРА И КРОВЕНАПОЛНЕНИЯ МИОКАРДА ПРИ ИШЕМИЧЕСКОМ И ВОСПАЛИТЕЛЬНОМ ПОВРЕЖДЕНИИ
}

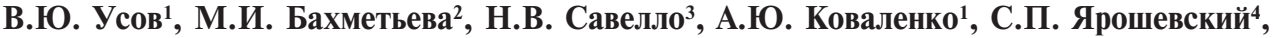 \\ О.В. Мочула ${ }^{1}$, М.Л. Белянин ${ }^{4}$ Ю.Б. Лишманов ${ }^{1,4}$, О.И. Беличенко ${ }^{5}$ \\ ${ }^{1}$ Научно-исследовательский институт кардиологии Томского национального исследовательского \\ медицинского центра РАН, Томск, Россия \\ ${ }^{2}$ Московский государственный университет им. М.В. Ломоносова, Москва, Россия \\ ${ }^{3}$ Компания Р-Фарм, Санкт-Петербург, Россия \\ ${ }^{4}$ Национальный исследовательский Томский политехнический университет, Томск, Россия \\ ${ }^{5}$ Научно-исследовательский институт спортивной медицины Российского государственного \\ университета физической культуры, спорта, молодежи и туризма, Москва, Россия
}

Цель. Разработать и апробировать в клинике методику количественного расчета проницаемости гистогематического барьера миокарда для контраста-парамагнетика на основе математической модели Гьедде - Рутланда - Патлака (ГРП) с оценкой роста содержания контраста в миокарде и его клиренса из крови по данным динамической МРТ.

Материал и методы. В основе модели накопления парамагнетика в поврежденном миокарде - принцип Гьедде - Рутланд - Патлака (1977). Если $C_{\text {миок }}-$ содержание контраста в миокарде, $C_{\text {кровь }}-$ содержание в крови, а $k_{\text {кровь-миокард }}-$ показатель скорости диффузии «кровь - миокард», считая транспорт парамагнетика однонаправленным в течение первых минут после инъекции, то, откладывая $\left\{\left(\int C_{\text {кровь }}(t) d t\right) / C_{\text {кровь }}\right\}-$ по оси $X$, а $\left\{C_{\text {миок }} / C_{\text {кровь }}\right\}-$ по оси $Y, k_{\text {кровь-миокард }}$, получается тогда как линейный наклон такого графика, а удельное кровенаполнение $V_{0}$ (мл/100 см ${ }^{3}$ ткани) - интерсепт по оси ординат.

Обследованы пациенты с острым инфарктом миокарда с успешным тромболизистом $(n=21)$ и впервые выявленной воспалительной патологией $(n=9)$. МРТ с парамагнитным контрастным усилением проводилось с помощью динамического протокола FFE1.7.ssfp330k MP-томографа Toshiba Titan при введении 2 мл 0,5 М гадоверсетамида на 10 кг веса тела, в матрицу $256 \times 256$ с показателями $\mathrm{TR}=3,4$ мс, $\mathrm{TE}=1,7$ мс, временем инверсии 176,0 мс, углом отклонения $=40$ град, толщиной среза $=8-10$ мм, показателем длины эхо (echo train length) $=1$. Запись данных велась до 12 мин, 1 кадр в 30 с и затем обрабатывалась с помощью RadiAnt (Medixant, Познань, Польша), и оригинальной программой динамического ана- лиза на MATLAB и SCILAB с построением графика ГРП, и расчетом $k_{\text {кровь-миокард }}$ и $V_{0}$.

Результаты. Физиологический смысл $k_{\text {кровь-миокард }}$ в том, что эта величина представляет собой клиренс крови по Gd-ДТПА в миокард, т.е. количество крови, очищаемое от парамагнетика за минуту единицей объема ткани миокарда. Показатель $k_{\text {кровь-миокард }}$ составил у пациентов с острым инфарктом миокарда с успешным тромболизистом и ЧКВ $(n=21) 3,09 \pm 1,32(2,36-$ $11,9)$ мл/мин/100 г ткани, тогда как у пациентов с хроническим миокардитом в обострении, или впервые выявленном остром миокардите $1,78 \pm 0,67(0,50-2,42)$ мл/мин/100 г ткани $(n=9)$. В норме $k_{\text {кровь-миокард }}$ составлял $0,09 \pm 0,06$ $(<0,2)$ (мл/мин/100 г ткани). Показатели кровенаполнения миокарда $V_{0}\left(\right.$ мл/100 $\left.\mathrm{cm}^{3}\right)$ составили в норме $2,9 \pm 0,8 \mathrm{mл} / 100 \mathrm{~cm}^{3}$, в очаге ишемического повреждения - 12,5 $\pm 4,6$ мл/100 $\mathrm{cm}^{3}$, а в зоне воспаления - до $14,12 \pm 5,27$ мл/100 см³. При воспалительном поражении кровенаполнение было повышено и за пределами зоны повреждения, до 4,1+0,8 мл/100 $\mathrm{cm}^{3}$.

Использование динамического протокола позволило высокодостоверно дифференцировать ишемическое и воспалительное поражение.

Заключение. Динамическое МРТ-исследование сердца с контрастным усилением и получаемые при математическом моделировании показатели диффузии парамагнетика в зоне повреждения и кровенаполнения миокарда различаются в зависимости от характера процесса и позволяют получить дополнительную патофизиологическую характеристику сосудистой проницаемости поврежденного гистогематического барьера при ишемии. 